\title{
geosciences
}

ISSN 2076-3263

www.mdpi.com/journal/geosciences

Article

\section{Evolving Phytoplankton Stoichiometry Fueled Diversification of the Marine Biosphere}

\author{
Ronald Martin ${ }^{1, *}$ and Antonietta Quigg ${ }^{2}$ \\ 1 Department of Geological Sciences, College of the Earth, Ocean, and Environment, \\ University of Delaware, Newark, DE 19716, USA \\ 2 Phytoplankton Dynamics Laboratory, Departments of Marine Biology and Oceanography, \\ Texas A\&M University at Galveston, Galveston, TX 77553, USA; E-Mail: quigga@tamug.edu \\ * Author to whom correspondence should be addressed; E-Mail: daddy@udel.edu; \\ Tel.:+1-302-831-6755; Fax: +1-302-831-4158.
}

Received: 29 March 2012; in revised form: 9 May 2012 / Accepted: 22 May 2012 /

Published: 31 May 2012

\begin{abstract}
The availability of nutrients and the quantity and quality of food at the base of food webs have largely been ignored in discussions of the Phanerozoic record of biodiversity. We examine the role of nutrient availability and phytoplankton stoichiometry (the relative proportions of inorganic nutrients to carbon) in the diversification of the marine biosphere. Nutrient availability and phytoplankton stoichiometry played a critical role in the initial diversification of the marine biosphere during the Neoproterozoic. Initial biosphere expansion during this time resulted in the massive sequestration of nutrients into biomass which, along with the geologically slow input of nutrients from land, set the stage for severe nutrient limitation and relatively constant marine biodiversity during the rest of the Paleozoic. Given the slow nutrient inputs from land and low recycling rates, the growth of early-to-middle Paleozoic metazoans remained limited by their having to expend energy to first "burn off" (respire) excess carbon in food before the associated nutrients could be utilized for growth and reproduction; the relative equilibrium in marine biodiversity during the Paleozoic therefore appears to be real. Limited nutrient availability and the consequent nutrient imbalance may have delayed the appearance of more advanced carnivores until the Permo-Carboniferous, when widespread orogeny, falling sea level, the spread of forests, greater weathering rates, enhanced ocean circulation, oxygenation, and upwelling all combined to increase nutrient availability. During the Meso-Cenozoic, rising oxygen levels, the continued nutrient input from land, and, especially, increasing rates of bioturbation,
\end{abstract}


enhanced nutrient availability, increasing the nutrient content of phytoplankton that fueled the diversification of the Modern Fauna.

Keywords: biodiversity; evolutionary fauna; metazoan; nutrients; phytoplankton

\section{Introduction}

The fossil record of marine biodiversity consists of three evolutionary faunas: Cambrian, Paleozoic, and Modern [1]. Although the exact levels of biodiversity exhibited by these faunas have come into question, the relative levels of biodiversity and the succession of the faunas through the Phanerozoic have remained robust in recent studies [2,3]. A variety of factors have been hypothesized to account for these patterns, among them changes in climate regime, sea level, biogeographic provinciality (due to changes in continent-ocean configurations and latitudinal temperature gradients), habitat area, and extinction [4,5].

We believe that underappreciated factors in the diversification of the marine biosphere are nutrient availability and the quantity and quality of food at the base of food webs. Helen Tappan [6-8] was among the first to draw attention to food availability as a critical factor in long-term trends of marine biodiversification. More recently, Bambach $[9,10]$ inferred that the "energetics" of the marine biosphere (biomass, metabolic rates, and physical activity such as predation) generally increased through geologic time in response to increasing food availability and, by implication, increasing nutrient availability. Martin [11] noted that the succession of the three macrofaunas is generally paralleled by the sequence of appearance of the dominant phytoplankton taxa through the Phanerozoic and their general preferences for increasingly nutrient-rich regimes [12]. Most recently, Bush and Bambach [13] concluded that increased ecological diversity, complexity, energy use, motility, predation, infaunality, and biological disturbance (bioturbation) have all increased since the Neoproterozoic. These trends largely parallel the diversification of the evolutionary faunas [13]. Predation and bioturbation appear to have increased through time especially during the Meso-Cenozoic (Figure 1), and require substantial amounts of energy because of their more advanced nervous and muscular systems [14,15]. Bush and Bambach [13] left open the question as to whether these trends are passive or driven, but singled out increasing primary productivity and thus, implicitly, nutrient availability, as the potential primary drivers.

Here, we integrate the results of our recent work on modern phytoplankton stoichiometry [16,17] with previous studies of the fossil record to propose a hypothesis for the role of phytoplankton evolution in the diversification of the marine biosphere. We suggest that the relative proportions of inorganic nutrients to carbon available in phytoplankton, i.e., their stoichiometry, evolved through time toward more nutrient-rich phytoplankton that were critical to the diversification of the marine biosphere.

The food represented by phytoplankton lies at the base of marine food pyramids and recent studies have found that not only the quantity but also the quality is critical to the maintenance, growth, and reproduction of organisms such as zooplankton which form a critical link between lower (phytoplankton) and upper (consumer) levels of food pyramids [18]. Zooplankton and metazoans must expend energy to "burn off" (respire) excess carbon in food before the associated inorganic nutrients can be utilized for growth and reproduction; thus, the more nutrient rich the phytoplankton, the less energy which must be expended to respire carbon and obtain the inorganic nutrients in food [18]. The conserved energy may then be devoted to other biological activities such as locomotion, predation, and reproduction, thereby driving increasing ecological complexity and, presumably, biodiversity. 
Figure 1. Marine biodiversity and environmental change through the late Proterozoic and Phanerozoic (adapted from [19]). (a) Sea level, tectonic cycles, and relative oxygen levels; (b) Terrestrial events: orogenies and land plant evolution (italics). Snowflakes indicate times of well-developed glaciers; (c) Comparison of mean Phanerozoic global isotopic signature of ${ }^{87} \mathrm{Sr} /{ }^{86} \mathrm{Sr}$ (dashed) and most recent calculation of subsampled number of marine genera (dotted; [2]). Original ${ }^{87} \mathrm{Sr} /{ }^{86} \mathrm{Sr}$ data from [20,21]). Increasing strontium isotope $\left({ }^{87} \mathrm{Sr} /{ }^{86} \mathrm{Sr}\right)$ are used as a general qualitative indicator of increased continental weathering and runoff [21,22]; these inferences have recently been confirmed by lithium isotope data [23]; (d) Geologic range and relative diversity of major phytoplankton taxa discussed in text; (e) Marine macroevolutionary faunas and family diversity from Sepkoski [1]. Note parallel diversification and decline of Paleozoic and Modern faunas and green and red algal taxa. Arrows indicate Big Five mass extinctions; (f) Bioturbation rates [14] and C:P burial ratios [19]. C:P burial ratios represent the ratio of marine carbon and phosphorus of the same samples and are used to indicate the relative remineralization of carbon [19], as discussed in the text. Note behavior of C:P burial ratios relative to bioturbation rates as discussed in the text.

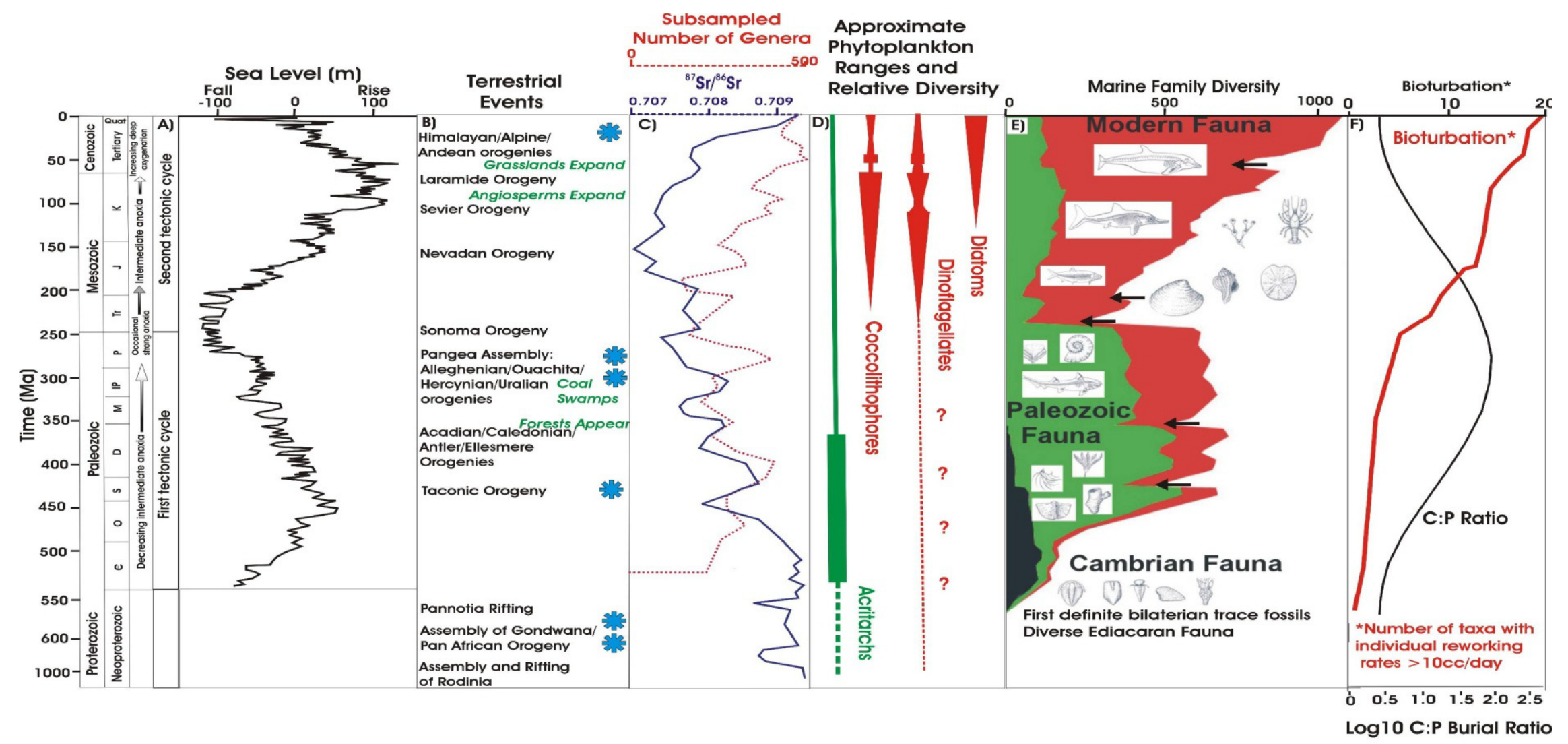




\section{The Fossil Record of Plankton}

The availability of nutrients determines the population densities of plankton, in turn simultaneously impacting the representation of plankton in the fossil record and the quantity (primary production) and quality (stoichiometry) of food at the base of food pyramids. The fossil record of plankton, in particular that of calcareous plankton, provides clues to the availability of nutrients and food in the oceans through time. Modern species of coccolithophores tend to live in ocean waters characterized by low levels of macronutrients (oligotrophic conditions), whereas modern dinoflagellates and, especially, diatoms are frequently associated with higher nutrient levels [12,24-26]. (The recently-reported decline of Cenozoic diatom diversity after the Eo-Oligocene by Rabosky and Sorhanuus [27] may reflect sampling procedures.) There are, however, scattered reports of relatively robust calcareous zooplankton (entomozoans, tentaculitids) and much smaller phytoplankton as early as the Silurian, including coccolithophores or coccolithophore-like objects [28-33]. Nevertheless, a number of the reports of calcareous phytoplankton are considered unreliable because the fossils were not properly described or have been dismissed as contamination from younger sediments [34].

But, if calcareous zooplankton were present in the Paleozoic, why was the appearance of undoubted calcareous phytoplankton delayed until the Mesozoic? The easiest and most widely accepted answer to this enigma is that the appearance of coccolithophores in the fossil record accurately reflects their first evolutionary occurrence. However, molecular clocks indicate that the organic plate scales that serve as templates in calcification among coccolithophores must have appeared no later than the mid-Paleozoic while the biochemical pathways used in coccolithogenesis (coccolithophore biomineralization) may have existed in the Paleozoic or even earlier [35]. Similarly, biomarkers said to be characteristic of taxa that diversified during the Mesozoic (coccolithophores and dinoflagellates) are present, in low abundance, during the Paleozoic [36-38]. If taken at face value, these biomarker studies suggest the presence of these taxa in at least low numbers during the Paleozoic.

Another clue comes from the chemical composition of the plankton found in the geologic record of the Paleozoic. Early-to-middle Paleozoic plankton are mostly non-calcareous, and therefore resistant to dissolution. Possibly, the Calcite Compensation Depth (CCD) of the oceans was so shallow during the early-to-middle Paleozoic that any calcareous phytoplankton as small as coccolithophores (1-25 $\mu \mathrm{m}$; [39]) that lived in open ocean waters dissolved [40]. Based on the $\mathrm{CaCO}_{3}$ content of deep-sea cores, van Andel [41] concluded that the CCD was as shallow as $\sim 3-3.5$ kilometers during the Cretaceous, when thick calcareous oozes formed in the epeiric seas. Stromatoporoid reefs thrived in epeiric seaways during the Early-to-Middle Paleozoic, when the predominant site of limestone deposition appears to have been on the cratons; cratonic limestone deposition during the early-to-middle Paleozoic is thought to have caused the CCD to shallow to only $\sim 0.5 \mathrm{~km}$ depth [40,42]. Bown et al. [43] also state that diagenesis of coccolithophores is faster in calcareous sediments than hemipelagic ones. The presence of "calcite oceans" associated with increased hydrothermal exchange during the rifting of Pangea has been suggested to explain the appearance of unambiguous calcareous plankton during the Mesozoic [44,45]. Possibly this explains the first appearance of planktonic foraminifera, but calcite oceans were also present during the first half of the Paleozoic, when supercontinent rifting was also occurring, and, as noted above, at least some relatively robust calcareous zooplankton were present during the Paleozoic. 
Coccolithogenesis itself impacts preservational issues. Recent studies of coccolithogenesis reveal that this process can be quantitatively and qualitatively regulated by environmental conditions and/or the life cycle stages of cells $[35,46,47]$. These studies have found naked or poorly calcified haptophyte cells in response to environmental perturbations such as changing $\mathrm{CO}_{2}$ concentrations. Rifting, seafloor spreading, and subduction during the first half of the Paleozoic likely pumped enormous amounts of carbon dioxide into the atmosphere, promoting dissolution in the photic zone (via an ancient version of "oceanic acidification") and diagenesis of oozes which may have formed in the epeiric seas flooding the continents during supercontinent breakup [48]. Much of the carbon dioxide of the Paleozoic must have remained in the atmosphere because continental weathering is quite slow and terrestrial forests, which would have otherwise sequestered carbon dioxide in terrestrial plant biomass, did not become widespread until the Late Devonian and Carboniferous (Figure 1). Holococcoliths in particular are rarely preserved because of their small $(<3 \mu \mathrm{m}$ long) and delicate nature, resulting in rapid dissolution before burial $[34,35,43]$. Bown et al. $[34,43]$ state that only a small proportion of calcareous plankton species are large enough or sufficiently calcified to be routinely preserved in the fossil record, and that most coccolithophore diversity is lost among holococcoliths, especially in deeper waters. Consequently, holococcoliths tend to characterize shelfal sediments up to a few hundred meters depth [39,43]. Similarly, Young et al. [49] reported that only certain types of coccoliths are resistant to dissolution, so that as little as $\sim 30 \%$ of the modern diversity slowly accumulates in deep oceanic sediments.

Interestingly, either phosphorus or nitrogen limitation results in the production of abnormal coccoliths in certain cultivated strains of Emiliania huxleyi $[24,46]$. These results indicate that the processes of coccolith production and calcification, and hence the abundance and preservation potential of coccolithophores in the fossil record, is also closely connected to nutrient metabolism [46], including that of calcium and phosphate [35]. Indeed, calcification among open ocean coccolithophores tends to be robust and appears linked to the long-term stability of oligotrophic-to-mesotrophic waters offshore [25], whereas coastal and neritic coccolithophores often produce small and poorly calcified coccoliths and the haploid stages of the life cycles of modern forms are frequently non-calcifying [35].

\section{Nutrients and the Evolution of Major Algal Lineages}

Diatoms and undoubted dinoflagellates appeared in the geologic record during the Mesozoic. Together with coccolithophores, these taxa have been grouped under the informal heading of "red" algal lineages primarily on the basis of their chlorophyll-c plastids ([50,51]; Figure 1). An examination of their elemental profiles indicates that trace elements were important in defining the evolutionary trajectory of these groups of phytoplankton, which all have higher quotas for manganese, cobalt and cadmium and lower quotas for iron, zinc and copper; these quotas are more-or-less evolutionarily conserved [16,17]. Wilde et al. [52] earlier suggested that higher oxygen levels promoted the presence of dissolved molybdenum and other trace elements, biolimiting micronutrients essential to the photosynthetic pathways of coccolithophores $[16,17,50]$, whereas iron, zinc and copper would have been less bioavailable in an oxygenated ocean. Given that the micronutrient (e.g., trace metal) requirements are evolutionarily conserved among modern algal lineages which have been examined [17], we suggest that specific micronutrient levels were insufficient to sustain large populations of red lineages such as coccolithophores during the Paleozoic. If ancestral red algal lineages were in fact 
present during the earlier Paleozoic, they may have been confined to shallow, oxygenated, coastal waters and may have fed via mixotrophy, only later acquiring red plastids via secondary endosymbiosis [35]. This is the case for dinoflagellates [53,54].

During the Cambrian through Devonian periods, by contrast, marine eukaryotic phytoplankton were dominated by acritarchs. These forms are considered by some to include the earliest green algal lineages [50], which use chlorophyll-b in photosynthesis and have higher requirements for iron, zinc and copper [16,17] (although larger forms are now considered to have been resting stages of multicellular algae or Ediacarans; [55,56]). Iron would presumably have been much more soluble under the low oxygen conditions of the early-to-middle Paleozoic. Indeed, prasinophytes, which have known green algal affinities, temporarily re-established themselves during anoxic events of the Mesozoic, signaling a temporary return to Paleozoic conditions [57].

But oxygen and micronutrient levels may not be the whole story. The most important macronutrients limiting primary production in the modern seas are nitrogen and phosphorus [12,58,59]; only diatom growth is limited by the availability of silica. Nitrogen is an essential component of amino acids (the building blocks of proteins) and phospholipids (used in cell membrane construction) whereas phosphorus is essential to the construction of DNA and RNA (found in ribosomes and messenger RNA), both of which are involved in information storage and transfer and cell division, and to ATP, which is used in energy capture, storage, and transfer [18]. Phosphorus is particularly important to RNA synthesis because of its vital role in protein synthesis. Consequently, according to this "growth rate hypothesis" [60], ecosystem conditions that produce organic matter with low C:P or N:P ratios should result in higher adaptive growth rates, more efficient energy transfer upward through food pyramids, and, notably, increased biomass of large-bodied animals (including invertebrates) relative to small ones, i.e., increased energetics $[9,10,13]$. The growth rate hypothesis has received support from several ecological and biogeographic studies since it was first proposed [61-64].

Nonetheless, there continues to be a debate as to which macronutrient, nitrogen or phosphorus, is the primary limiting nutrient of marine primary productivity in the seas $[58,59,65]$. This debate spans not only the different ecospaces of the oceans but the eons. Denitrification is accelerated in anoxic waters, which were widespread during the first half of the Paleozoic Era (Figure 1). By contrast, phosphorus is thought to be released under the same conditions [66]). Thus, nitrogen would seem to have been the primary limiting nutrient in early-to-middle Paleozoic oceans. However, recent studies by Goldhammer et al. [67] found that much of the phosphorus released under anoxic conditions in sediment is sequestered into authigenic apatite by bacterially-mediated precipitation; iron may have also contributed to phosphorus precipitation [68]. If this was the case for early-to-middle Paleozoic oceans, then phosphorus may instead have been the primary limiting nutrient. The primary limiting nutrient also appears to depend on the duration of the time scale selected. Tyrrell [58], based on a two-box model, concluded that under steady-state conditions surface ocean waters are more deficient in nitrate than phosphate but that phosphorus is the ultimate limiting nutrient and that external inputs of phosphorus (like those from land; [11]) regulate longer-term total primary productivity. 


\section{The Shift from Green to Red Phytoplankton Lineages}

The shift from green to red phytoplankton lineages may have actually begun during the late Paleozoic. Oxygen levels likely began to increase during the Carboniferous as atmospheric carbon dioxide levels were drawn down by forests. Carbon-rich black shales were much more widespread during the first half of the Paleozoic than during the Permo-Carboniferous, and even less so during the Mesozoic, when black shale deposition was largely restricted to much more episodic oceanic anoxic events (Figure 1). The Permo-Carboniferous also coincides with the "Phytoplankton Blackout" of Riegel [69], who attributed it to nutrient decline that resulted from the radiation of forests and nutrient sequestration in terrestrial plant biomass (see also [7,8]). By contrast, Pitrat [70] cited evidence for abundant food supplies during the Permo-Carboniferous and Schwark and Empt [38] noted a sharp increase in steranes indicative of more modern algae across the Devonian-Carboniferous boundary. Other possibilities for the green to red shift have been discussed by Falkowski et al. [71].

The Permo-Carboniferous is also when the diversity and abundance of acritarchs greatly declined, never to recover their previous diversity in the fossil record (Figure 1; [36]). Widespread orogeny, sea level fall, and the spread of terrestrial forests during the Permo-Carboniferous would have increased the rates of erosion and weathering (including previously deposited shallow-water limestones of the earlier Paleozoic) and nutrient runoff into the seas (Figure 1). Rising nutrient levels during the Permo-Carboniferous is corroborated by the broad rise in strontium isotopes during the Permo-Carboniferous (Figure 1); increasing strontium isotope values are generally inferred to indicate increased continental weathering and runoff on long geologic scales of time [11,21-23]. Well-developed continental glaciers were also present in the southern hemisphere during most of the Permo-Carboniferous, presumably promoting relatively rapid circulation and oxygenation of the oceans and the upwelling of waters enriched in phosphorus and redox-sensitive trace metals such as molybdenum.

The further spread of terrestrial forests during the Mesozoic, coupled with warm humid conditions, may have increased weathering rates on the continents. The resulting nutrients would have run off into the shallow epeiric seas where red lineages of plankton were able to begin to thrive in a very widespread, and typically more oxygenated photic zone [71,72]. In fact, most of the world's petroleum source rocks fall within the Mesozoic and Cenozoic [73].

\section{Implications for the Phanerozoic Record of Marine Biodiversity}

Our inferences point to the importance of nutrients as a control on marine biotic origination and diversification. The most recent iteration of the Phanerozoic generic marine diversity curve [2] is broadly paralleled by the strontium isotope curve (Figure 1); although the correspondence is not exact (likely due in part to different treatments of the raw data sets, chronologies, etc.), the resemblance of the curves is certainly suggestive of a relationship. Of the various factors examined (including sea level, $\delta^{18} \mathrm{O}, \delta^{13} \mathrm{C}$ ), Cárdenas and Harries [74] found a significant positive correlation only between changes in marine generic origination rates and ${ }^{87} \mathrm{Sr} /{ }^{86} \mathrm{Sr}$ (see also [11,75-77]. Cárdenas and Harries [74] further concluded that the $\delta^{34} \mathrm{~S}$ signature reflects the efficiency of phosphorus recycling and oxygen levels which as, discussed above, likely influenced nutrient availability. Marine biodiversity and the 
sulfur cycle (and the related carbon cycle) are in turn related to the broad changes in sea level associated with the tectonic (Wilson) cycle (Figure 1; [3]).

The first tectonic cycle of the Phanerozoic spans the Paleozoic Era (Figure 1). Marine faunas of the Paleozoic were initially represented by the Cambrian Fauna, which evolved during the so-called "Cambrian Explosion" of marine biodiversity. The Cambrian Fauna was dominated by taxa which fed relatively close to the sediment-water interface and which presumably had relatively low metabolic rates [9]. (The predatory habit of Anomalocaris, long thought to be the Cambrian's dominant hunter, has also recently been questioned; [78]). The Cambrian Fauna gradually gave way during succeeding periods to the Paleozoic Fauna, in which predation became more evident with the appearance of cephalopods early on and eventually durophagous (shell-crushing) predators by the Permo-Carboniferous [79]. Despite repeated extinction, which should seemingly have encouraged evolutionary novelty and biodiversification like that seen during the Meso-Cenozoic, the archaic communities of the Paleozoic maintained a relatively constant level of diversity until the end of the Permian, when they were mostly extinguished (Figure 1).

The second tectonic cycle of the Phanerozoic extends from the beginning of the Mesozoic to the present. Sessile taxa such as crinoids, which had fed as much as a meter above bottom, began to retreat toward the sediment-water interface while much of the rest of the benthos began to burrow ever deeper into the sediment, all presumably in response to increasing predation and cropping [80]. Thus, the energetics of the marine biosphere appears to have been increasing [9]. Despite continued input of external nutrients from land and increasing nutrient content of phytoplankton, the biosphere likely remained severely nutrient limited throughout the Phanerozoic. External inputs of nutrients would have been increasingly sequestered into living, and thus also dead, biomass of the marine and terrestrial realms as the biosphere continued to expand. The sequestration of nutrients into living and dead biomass of an ever-expanding biosphere would have made nutrients effectively unavailable for photosynthesis.

Thus, an acceleration of the rate of the remineralization of dead organic matter and the recycling of nutrients back to the photic zone would have been necessary to keep pace with, and sustain, an expanding biosphere. Increasing biodiversity in turn promotes increasing rates of ecosystem processes such as bioturbation, organic matter remineralization, and nutrient regeneration $[81,82]$. In fact, the expansion of the Modern Fauna is paralleled by increasing rates and depths of bioturbation (Figure 1) and the remineralization of marine organic carbon through the Meso-Cenozoic, as reflected by decreasing C:P burial ratios (Figure 1; [19]).

The availability of macronutrients like phosphorus to plankton would have affected not only the amount of food available at the base of marine food pyramids, but also the quality (inorganic nutrient content) of food. Of the three basic consumer strategies present in ecosystems, detritivores, herbivores, and carnivores, the latter eat the most nutritionally-balanced foods (animals eating animals) and consistently exhibit the highest growth efficiencies and assimilation, or conversion of food to their own biomass [18]. By contrast, detritivores such as burrowing organisms eat the least nutritious foods (animals eating non-living matter) and have low growth efficiencies and assimilation. Herbivores occupy an intermediate position [18]. The predominant green phytoplankton lineages of the Paleozoic appear to have been nutrient-poor (i.e., carbon-rich) as compared to the later red lineages of the Mesozoic Era. Quigg et al. [16,17] found that the ratio of carbon-to-phosphorus in cultivated lineages of modern green algal species is much higher than that of red lineages. Green lineages therefore appear 
to have been adapted to nutrient-poor conditions during the early-to-middle Paleozoic. Consequently, the growth of early-to-middle Paleozoic metazoans may have been limited by their having to expend energy to first "burn off" (respire) excess carbon in food before the associated nutrients could be utilized for growth and reproduction. Given the slow nutrient inputs from land and low recycling rates, nutrient pulses associated with orogeny may have initially promoted eutrophication and destabilization of marine ecosystems associated with intervals of extinction while also eventually promoting phytoplankton diversification and biodiversification $[11,82,83]$. Limited nutrient availability and the consequent nutrient imbalance may have delayed the appearance of more advanced carnivores until the Permo-Carboniferous, when widespread orogeny, falling sea level, the spread of forests, greater weathering rates, enhanced ocean circulation, oxygenation, and upwelling all combined to increase nutrient availability (Figure 1). Although it fluctuated, the relative equilibrium in marine biodiversity during the Paleozoic would therefore appear to be real.

Interestingly, crown metazoan taxa of the Modern Fauna appeared by the Cambrian [84] but did not begin to diversify substantially until the Mesozoic, despite repeated mass and minor extinctions of the Paleozoic Fauna that might otherwise have allowed the Modern Fauna to gain a larger foothold, as it did in the Triassic (Figure 1). Moreover, representatives of both the Paleozoic and Modern faunas tended to diversify from nearshore environments into offshore environments [85], perhaps tracking the evolution of phytoplankton. We conclude that the diversification of the Modern Fauna during the Meso-Cenozoic reflects the appearance of food quantity and quality sufficient to enhance metabolism and biomass, i.e., increasing population densities of red algal lineages such as the coccolithophores.

\section{Food and the Emergence of Metazoans in the Fossil Record}

If phytoplankton stoichiometry was critical to marine biodiversification during the Phanerozoic, then perhaps it was also intimately involved in the early diversification of the marine biosphere. The appearance of larger metazoans is typically attributed to rising oxygen levels in the atmosphere and oceans. Bangiophyte (red multicellular algae) from $\mathrm{Ga}$, for example, are inferred to indicate rising oxygen levels but these would have still been much lower than at later times in Neoproterozoic [86]. Rising oxygen levels are thought to have triggered a trophic cascade-like process like those of lake ecosystems, but prolonged over geologic scales of time, possibly in response to enhanced phosphorus input from land $[19,87,88]$. But food quantity and, especially, food quality (autotroph stoichiometry) must have also been critical to early metazoan evolution; otherwise, the aerobic respiration of less nutritious carbon-rich substrates would have yielded less energy (ATP).

Modern trophic cascades are said to result primarily from the "top-down" control of community structure by upper trophic levels (herbivorous zooplankton and predators) that affect multiple lower trophic levels [18]. Herbivorous zooplankton involved in modern cascades are fast-growing and have high nutrient demands and thus are strongly constrained by "bottom-up" phytoplankton nutrient content, i.e., carbon-to-phosphorus (C:P) ratios of autotroph biomass must at least approximate "Redfield" ratios of 106:1 or less to sustain modern zooplankton metabolism [18,89]. Faster-growing zooplankton appear to have lower $\mathrm{C}: \mathrm{P}$ ratios because faster growth requires more phosphorus for the production of nucleic acids during cell division [65]. Cropping by mesozooplankton further increases nutrient cycling, thereby 
maintaining autotroph populations in a state of relatively rapid growth and increasing their nutrient content; increasing food quality in turn allows additional trophic levels to be added [18].

We therefore suggest that, prior to the Neoproterozoic-Phanerozoic transition, marine ecosystems resembled modern "stoichiometrically-imbalanced" ecosystems, in which eukaryotic autotrophs fix large amounts of carbon despite low dissolved nutrient levels [18]. Under imbalanced conditions in modern ecosystems, nutrient use efficiency (=rate of $\mathrm{C}$ fixed per unit nutrient) of autotrophs is high but carbon use efficiency (=secondary production/primary production) by herbivores is low because the food is nutrient-poor (carbon-rich) and excess carbon must be respired by animals to obtain nutrients necessary for growth $[18,89]$. The initial appearance of metazoan bioturbators (detritivores) during the transition, followed by herbivores and carnivores in the fossil record, in turn suggests that marine ecosystems were moving toward a "stoichiometrically-balanced"state [18]. Under these conditions in modern ecosystems, phytoplankton produce biomass of approximately Redfield proportions under more-or-less nutrient-saturated conditions that are capable of consistently sustaining higher trophic levels [18].

Where would the nutrients have come from to increase food quantity and quality to stimulate metazoan evolution? Possibly from the widespread orogeny and glacial weathering that occurred just before the Paleozoic Era [21,88]. Like the Permo-Carboniferous, there is a significant broad increase of strontium isotope ratios during the few hundred million years preceding the Paleozoic Era. The rise of these ratios in the late Precambrian is so great that it not only surpasses that of the Permo-Carboniferous but also the rise that accompanied the formation of mountain belts all over the world during the Cenozoic (Figure 1; [21]).

Two recent field experiments serve as modern analogs for the early diversification of metazoans that is hypothesized to have resulted from increasing food and nutrient availability. The experimental input of phosphorus to the ultraoligotrophic (extremely nutrient-poor), phosphorus-starved surface waters of the eastern Mediterranean near Cyprus by Thingstad et al. [90] stimulated the rapid uptake of phosphorus by phytoplankton and bacteria well above the concentrations immediately required for growth, making the plankton more nutrient-rich. The intracellular phosphorus was then transferred through the food chain into zooplankton populations much more rapidly than normally occurs in marine ecosystems. In another field experiment, Elser et al. [91] added phosphorus to a stromatolitic community, not unlike those which existed during the late Precambrian and the Early Paleozoic. Phosphorus enrichment of these communities lowered the carbon-to-phosphorus ratios of stromatolite biomass from $\sim 800-1100$ to $\sim 150$ (compare green phytoplankton lineages of Quigg et al. [16], at which point growth, biomass, and survivorship of grazing snails significantly increased.

Nutrient inputs may have initially fueled rapid biomass increase. Increasing autotroph biomass would presumably have resulted in increasing rates of photosynthesis, as suggested by the shift of the carbon isotope curve to more positive values; the strong shifts in carbon isotopes during the Proterozoic-Phanerozoic transition may reflect the influence of Snowball Earth episodes on primary productivity or vice versa. Increased rates of photosynthesis during this interval would have in turn increased rates of oxygenation of the oceans and atmosphere, long thought to be the supposed prime driver of early metazoan evolution.

However, we also suggest the eventual onset of severe nutrient limitation during the Proterozoic-Phanerozoic transition because of the massive, geologically-rapid uptake of nutrients into biomass (see also [92]). Organisms of higher trophic levels tend to become enriched in phosphorus 
because of the widespread phosphorus-dependent energy transfer and information storage pathways involved in protein synthesis [18]. Massive nutrient sequestration may have set the stage for the relatively constant marine biodiversity of the Paleozoic, given the relatively nutrient-poor conditions hypothesized for this era. Martin [11] earlier suggested that marine surface waters of this time were so nutrient-poor ("superoligotrophic") that they inhibited biosphere evolution.

Several lines of evidence support the inference of severe nutrient limitation during the Proterozoic-Phanerozoic transition despite higher nutrient runoff. First, phosphorite deposition first became pronounced during the late Neoproterozoic-Phanerozoic transition [93]. Although phosphorite deposition depends on the remineralization of dead organic matter with its sequestered nutrients [93], phosphorite deposition may have removed nutrients released by remineralization. Second, acritarchs averaged $\sim 20 \mu \mathrm{m}$ in diameter, which falls toward the lower limits of eukaryotic microplankton (range: $20-200 \mu \mathrm{m})$ and nannoplankton $(2-20 \mu \mathrm{m})$ of the Meso-Cenozoic [94]; the extremely small size of acritarchs suggests increasing surface-to-volume ratios as an adaptation to nutrient-poor conditions [11,95]. Similar patterns occurred in the Cenozoic; changes in diatom and dinoflagellate sizes in this period have been correlated to changes in nutrient availability [96,97]. Third, once triggered, rapid biosphere expansion would have necessitated the onset of nutrient recycling to sustain biosphere metabolism on ecologic time scales and biosphere complexification on geologic ones, so that depths of bioturbation began to increase early in the Paleozoic [13,80,98].

\section{Conclusions}

Phytoplankton population densities, especially those of the Paleozoic, were severely constrained by nutrient availability and stoichiometry, thereby affecting their preservation in the fossil record. Calcareous (and other) phytoplankton characteristic of the Mesozoic may have existed during the Paleozoic but only in numbers insufficient or in environments too restricted to be preserved in the fossil record because of an extremely shallow $\mathrm{CCD}$ and accelerated diagenesis due to elevated atmospheric carbon dioxide.

The shift to more nutrient-rich phytoplankton may have begun during the late Paleozoic, as hinted by biomarkers and petroleum source rocks. Widespread orogeny, sea level fall, glaciation, oceanic overturn and upwelling, oxygenation, and the spread of terrestrial forests during the Permo-Carboniferous would have increased the rates of weathering, erosion, and nutrient runoff into the seas. Along with the erosion of shallow-shelf limestones via sea-level fall, these processes may have provided positive feedback on the deepening of the CCD, eventually leading to the more widespread deposition and preservation of deep-sea calcareous oozes in the Mesozoic.

Food quantity and quality in turn impacted the diversification of the marine biosphere and its fossil record. The availability of macronutrients like phosphorus to plankton would have affected not only the amount of food available at the base of marine food pyramids, but also the quality (nutrient content) of that food. Increasing food quantity and quality parallels the increasing "energetics" (carrying capacity, metabolic rates, and physical activity) of the marine biosphere inferred from the fossil record of evolutionary faunas, especially during the Meso-Cenozoic with the tremendous expansion of the Modern Fauna. Zooplankton and metazoans must expend energy to "burn off" (respire) excess carbon in food before the associated nutrients can be utilized for growth and reproduction; thus, the more nutrient rich 
the phytoplankton, the less energy which must be expended to respire carbon and obtain the nutrients in food.

We further suggest that food quantity and, especially, food quality were critical to the emergence of metazoans during the Proterozoic-Phanerozoic transition. Prior to the Neoproterozoic-Phanerozoic transition, marine ecosystems resembled modern "stoichiometrically-imbalanced" ecosystems, in which eukaryotic autotrophs fix large amounts of carbon despite low dissolved nutrient levels. The eventual appearance of herbivores and carnivores in the fossil record during the transition in turn suggests that marine ecosystems were moving toward a "stoichiometrically-balanced" state. Under these conditions in modern ecosystems, phytoplankton produce biomass of approximately Redfield proportions that can sustain higher trophic levels.

Once triggered, rapid biosphere expansion resulted in the massive sequestration of nutrients into biomass and severe nutrient limitation. Massive nutrient sequestration may have set the stage for the relatively constant marine biodiversity of the Paleozoic, given the relatively nutrient-poor conditions hypothesized for this era.

\section{Acknowledgements}

We thank the Editors of Geosciences for their invitation to contribute to this special issue. We also thank two anonymous reviewers whose reviews helped better focus the manuscript, especially Richard Bambach for his encouraging comments.

\section{References}

1. Sepkoski, J.J. A factor analytic description of the Phanerozoic marine fossil record. Paleobiology 1981, 7, 36-53.

2. Alroy, J. The shifting balance of diversity among major marine animal groups. Science 2010, 329, 1191-1194.

3. Hannisdal, B.; Peters, S.E. Phanerozoic earth system evolution and marine biodiversity. Science 2011, 334, 1121-1124.

4. Benton, M.J. The Red Queen and the court jester: Species diversity and the role of biotic and abiotic factors through time. Science 2009, 323, 728-732.

5. Marshall, C.R. Marine biodiversity dynamics over deep time. Science 2010, 329, 1156-1157.

6. Tappan, H. Primary production, isotopes, extinctions and the atmosphere. Palaeogeog. Palaeoclimatol. Palaeoecol. 1968, 4, 187-210.

7. Tappan, H. Microplankton, Ecological Succession and Evolution; North American Paleontological Convention: Chicago, IL, USA, 1971; part H, pp. 1058-1103.

8. Tappan, H. Phytoplankton: Below the salt at the global table. J. Paleontol. 1986, 60, 545-554.

9. Bambach, R.K. Energetics in the global marine fauna: A connection between terrestrial diversification and change in the marine biosphere. GeoBios 1999, 32, 131-144.

10. Bambach, R.K. Seafood through time: Changes in biomass, energetics, and productivity in the marine ecosystem. Paleobiology 1993, 19, 372-397.

11. Martin, R.E. Secular increase in nutrient levels through the Phanerozoic: Implications for productivity, biomass, and diversity of the marine biosphere. Palaios 1996, 11, 209-219. 
12. Kilham, P.; Kilham, S.S. The evolutionary ecology of phytoplankton. In The Physiological Ecology of Phytoplankton; Morris, I., Ed.; University of California Press: Berkeley, CA, USA, 1980; pp. 571-597.

13. Bush, A.M.; Bambach, R.K. Paleoecologic megatrends in marine metazoa. Ann. Rev. Earth Planet. Sci. 2011, 39, 241-269.

14. Thayer, C.W. Sediment-mediated biological disturbance and the evolution of marine benthos. In Biotic Interactions in Recent and Fossil Benthic Communities; Tevesz, M.J.S., McCall, P.L., Eds.; Plenum Press: New York, NY, USA, 1983; pp. 479-625.

15. Fox, R. Energy and the Evolution of Life; W.H. Freeman: New York, NY, USA, 2008; p. 182.

16. Quigg, A.; Finkel, Z.V.; Irwin, A.J.; Rosenthal, Y.; Ho, T.-Y.; Reinfelder, J.R.; Schofield, O.; Morel, F.M.M.; Falkowski, P.G. The evolutionary inheritance of elemental stoichiometry in marine phytoplankton. Nature 2003, 425, 291-294.

17. Quigg, A.; Irwin, A.J.; Finkel, Z.V. Evolutionary imprint of endosymbiosis of elemental stoichiometry: Testing inheritance hypotheses. Proc. R. Soc. London Ser. B 2011, 278, 526-534.

18. Sterner, R.W.; Elser, J.J. Ecological Stoichiometry: The Biology of Elements from Molecules to the Biosphere; Princeton University Press: Princeton, NJ, USA, 2002; p. 439.

19. Martin, R.E.; Quigg, A.; Podkovyrov, V. Marine biodiversification in response to evolving phytoplankton stoichiometry. Palaeogeog. Palaeoclimatol. Palaeoecol. 2008, 258, 277-291.

20. Veizer, J.; Ala, D.; Azmy, K.; Bruckschen, P.; Buhl, D.; Bruhn, F.; Carden, G.A.F.; Diener, A.; Ebneth, S.; Godderis, Y.; et al. ${ }^{87} \mathrm{Sr} /{ }^{86} \mathrm{Sr}, \delta^{13} \mathrm{C}$ and $\delta^{18} \mathrm{O}$ evolution of Phanerozoic seawater. Chem. Geol. 1999, 161, 59-88.

21. Montañez, I.P.; Osleger, D.A.; Banner, J.L.; Mack, L.E. Evolution of the Sr and C isotope composition of Cambrian oceans. GSA Today 2000, 10, 1-7.

22. Tardy, Y.; N'Kounkou, R.; Probst, J.-L. The global water cycle and continental erosion during Phanerozoic time (570 my). Am. J. Sci. 1989, 289, 455-483.

23. Misra, S.; Froelich, P.N. Lithium isotope history of Cenozoic seawater: Changes in silicate weathering and reverse weathering. Science 2012, 335, 818-823.

24. Egge, J.K.; Aksnes, D.L. Silica as regulating nutrient in phytoplankton competition. Mar. Ecol. Progr. Ser. 1992, 83, 281-289.

25. Aubry, M.-P. Early paleogene calcareous nannoplankton evolution: A tale of climatic amelioration. In Late Paleocene-Early Eocene Climatic and Biotic Events in the Marine and Terrestrial Records; Aubry, M.-P., Lucas, S., Berggren, W.A., Eds.; Columbia University Press: New York, NY, USA, 1998; pp. 158-203.

26. Riegman, R.; Stolte, W.; Noordeloos, A.A.M.; Slezak, D. Nutrient uptake and alkaline phosphatase (ec 3:1:3:1) activity of Emiliania huxleyi (Prymnesiophyceae) during growth under N and P limitation in continuous cultures. J. Phycol. 2000, 36, 87-96.

27. Rabosky, D.L.; Sorhannus, U. Diversity dynamics of marine planktonic diatoms across the Cenozoic. Nature 2009, 557, 183-186.

28. Pirini-Radrazzani, C. Coccoliths from Permian deposits of Eastern Turkey. In Proceedings of the II Planktonic Conference; Rome, Italy, 1971; Farinacci, A., Ed.; Edizioni Tecnoscienza: Rome, Italy, Volume 2, pp. 993-1001. 
29. Gartner, S.; Gentile, R. Problematic Pennsylvanian coccoliths from Missouri. Micropaleontology 1972, 18, 401-404.

30. Minoura, N.; Chitoku, T. Calcareous nannofossil and problematic microorganisms found in the late Paleozoic limestones. J. Fac. Sci. Hokkaido Univ. Series IV Geol. Miner. 1972, 19, 199-212.

31. Munnecke, A.; Samtleben, C.; Servais, T.; Vachard, D. SEM-observation of calcareous micro- and nannofossils incertae sedis from the Silurian of Gotland, Sweden: Preliminary results. Geobios 1998, 32, 307-314.

32. Munnecke, A.; Servais, T.; Vachard, D. A new family of calcareous microfossils from the Silurian of Gotland, Sweden. Palaeontology 2000, 43, 1153-1172.

33. Flügel, E.H. Microfacies of Carbonate Rocks: Analysis, Interpretation and Application; Springer Verlag: Berlin, Germany, 2010; p. 984.

34. Bown, P.R.; Lees, J.A.; Young, J.R. Calcareous nannoplankton evolution and diversity through time. In Coccolithophores: From Molecular Processes to Global Impact; Thierstein, H., Young, J.R., Eds.; Springer-Verlag: Berlin, Germany, 2004; pp. 481-508.

35. De Vargas, C.; Aubry, M.-P.; Probert, I.; Young, J. Origin and evolution of coccolithophores: From coastal hunters to oceanic farmers. In Evolution of Primary Producers in the Sea; Falkowski, P., Knoll, A.H., Eds.; Academic Press: New York, NY, USA, 2007; pp. 251-285.

36. Moldowan, J.M.; Dahl, J.; Jacobson, S.R.; Huizinga, B.J.; Fago, F.J.; Shetty, R.; Watt, D.S.; Peters, K.E. Chemostratigraphic reconstruction of biofacies: Molecular evidence linking cyst-forming dinoflagellates with pre-Triassic ancestors. Geology 1996, 24, 159-162.

37. Grantham, P.J.; Wakefield, L.L. Variations in the sterane carbon number distributions of marine source rock derived crude oils through geological time. Org. Geochem. 1988, 12, 61-73.

38. Schwark, L.; Empt, P. Sterane biomarkers as indicators of Palaeozoic algal evolution and extinction events. Palaeogeogr. Palaeoclimatol. Palaeoecol. 2006, 240, 225-236.

39. Perch-Nielsen, K. Mesozoic calcareous nannofossils. In Plankton Stratigraphy; Bolli, H.M., Saunders, J.B., Perch-Nielsen, K., Eds.; Cambridge University Press: Cambridge, UK, 1985; pp. 329-426.

40. Boss, S.K.; Wilkinson, B.H. Planktogenic/eustatic control on cratonic oceanic carbonate accumulation. J. Geol. 1991, 99, 497-513.

41. Van Andel, T.H. Mesozoic/Cenozoic calcite compensation depth and the global distribution of calcareous sediments. Earth Planet Sci. Lett. 1975, 26, 187-195.

42. Hüneke, H.; Henrich, R. Pelagic sedimentation in modern and ancient oceans. In Deep-Sea Sediments; Hüneke, H., Mulder, T., Eds.; Elsevier: Amsterdam, The Netherlands, 2011; pp. 215-351.

43. Bown, P.R.; Dunkley Jones, T.; Lees, J.A.; Randell, R.D.; Mizzi, J.A.; Pearson, P.N.; Coxall, H.K.; Young, J.R.; Nicholas, C.J.; Karega, A.; et al. A Paleogene calcareous microfossil KonservatLagerstätte from the Kilwa Group of coastal Tanzania. Geol. Soc. Am. Bull. 2008, 120, 3-12

44. Stanley, S.M.; Hardie, L.A. Hypercalcification: Paleontology links plate tectonics and geochemistry to sedimentology. GSA Today 1999, 9, 2-7.

45. Stanley, S.M.; Ries, J.B.; Hardie, L.A. Seawater chemistry, coccolithophore population growth, and the origin of Cretaceous chalk. Geology 2005, 33, 593-596.

46. Paasche, E. Roles of nitrogen and phosphorus in coccolith formation in Emiliania huxleyi (Prymnesiophyceae). Eur. J. Phycol. 1998, 33, 33-42. 
47. Riebesell, U. Effects of $\mathrm{CO}_{2}$ enrichment on marine phytoplankton. J. Oceanogr. 2004, 60, 719-729.

48. Walker, K.R.; Diehl, W.W. The role of marine cementation in the preservation of Lower Paleozoic assemblages. In Extraordinary Fossil Biotas: Their Ecological and Evolutionary Significance; Whittington, H.B., Conway Morris, S., Eds.; Scholium International, Inc.: Washington, NY, USA, 1985; Volume B311, pp. 143-153.

49. Young, J.R.; Geisen, M.; Probert, I. Review of selected aspects of coccolithophore biology with implications for paleobiodiversity estimation. Micropaleontology 2005, 51, 267-288.

50. Falkowski, P.G.; Katz, M.E.; Knoll, A.H.; Quigg, A.; Raven, J.A.; Schofield, O.; Taylor, F.J.R. The evolution of modern eukaryotic phytoplankton. Science 2004, 305, 354-360.

51. Hackett, J.D.; Yoon, H.S.; Butterfield, N.J.; Sanderson, M.J.; Bhattacharya, D. Plastid endosvmbiosis: Sources and timing of the major events. In Evolution of Primary Producers in the Sea; Falkowski, P., Knoll, A.H., Eds.; Academic Press: New York, NY, USA, 2007; pp. 109-132.

52. Wilde, P.; Lyons, T.W.; Quinby-Hunt, M.S. Organic proxies in black shales: Molybdenum. Chem. Geol. 2004, 206, 167-176.

53. Yoon, H.S.; Hackett, J.D.; Bhattacharya, D. A single origin of the peridinin- and fucoxanthin- containing plastids in dinoflagellates through tertiary endosymbiosis. Proc. Natl. Acad. Sci. USA 2002, 99, 11724-11729.

54. Yoon, H.S.; Hackett, J.D.; Pinto, G.; Bhattacharya, D. The single, ancient origin of chromist plastids. Proc. Natl. Acad. Sci. USA 2002, 99, 15507-15512.

55 Butterfield, N.J. A vaucheriacean alga from the middle Neoproterozoic of Spitsbergen: Implications for the evolution of Proterozoic eukaryotes and the Cambrian explosion. Paleobiology 2004, 30, 231-252.

56. Cohen, P.A.; Knoll, A.H.; Kodner, R.B. Large spinose microfossils in Ediacaran rocks as resting stages of early animals. Proc. Natl. Acad. Sci. USA 2009, 106, 6519-6524.

57. Van de Schootbrugge, B.; Bailey, T.; Rosenthal, Y.; Katz, M.E.; Wright, J.D.; Feist-Burkhardt, S.; Miller, K.G.; Falkowski, P.G. Early Jurassic climate change and the radiation of organic-walled phytoplankton in the Tethys Ocean. Paleobiology 2005, 31, 73-97.

58. Tyrrell, T. The relative influences of nitrogen and phosphorus on oceanic primary production. Nature 1999, 400, 525-531.

59. Howarth, R.; Marino, R. Nitrogen as the limiting nutrient for eutrophication in coastal marine environments: Evolving views over three decades. Limnol. Oceanogr. 2006, 51, 364-376.

60. Elser, J.J.; Dobberfuhl, D.R.; MacKay, N.A.; Schampel, J.H. Organism size, life history, and N:P stoichiometry. BioScience 1996, 46, 674-684.

61. Main, T.M.; Dobberfuhl, D.R.; Elser, J.J. N:P stoichiometry and ontogeny of crustacean zooplankton: A test of the growth rate hypothesis. Limnol. Oceanogr. 1997, 42, 1474-1478.

62. Gillooly, J.F.; Charnov, E.L.; West, G.B.; Savage, V.M.; Brown, J.H. Effects of size and temperature on developmental time. Nature 2002, 417, 70-73.

63. Mulder, C.; Elser, J.J. Soil acidity, ecological stoichiometry and allometric scaling in grassland food webs. Glob. Chang. Biol. 2009, 15, 2730-2738.

64. Allmon, W.D.; Ross, R.M. Nutrients and evolution in the marine realm. In Evolutionary Paleoecology: The Ecological Context of Evolutionary Change; Allmon, W.D., Bottjer, D.J., Eds.; Columbia University Press: New York, NY, 2001; pp. 105-148. 
65. Falkowski, P.G.; Rosenthal, Y. Biological diversity and resource plunder in the geological record: Casual correlations or causal relationships? Proc. Natl. Acad. Sci. USA 2001, 98, 4290-4292.

66. Ingall, E.; Jahnke, R. Influence of water-column anoxia on the elemental fractionation of carbon and phosphorus during sediment diagenesis. Mar. Geol. 1997, 139, 219-229

67. Goldhammer, T.; Brüchert, V.; Ferdelman, T.G.; Zabel, M. Microbial sequestration of phosphorus in anoxic upwelling sediments. Nat. Geosci. 2010, 3, 557-561.

68. Williams, R.J.P.; Frausto Da Silva, J.J.R. The Natural Selection of the Chemical Elements; Bath Press Ltd.: Bath, UK, 1996; p. 646.

69. Riegel, W. The Late Palaeozoic phytoplankton blackout - Artefact or evidence of global change? Rev. Palaeobot. Palynol. 2008, 148, 73-90.

70. Pitrat, C.W. Phytoplankton and the late Paleozoic wave of extinction. Palaeogeogr. Palaeoclimatol. Palaeoecol. 1970, 8, 49-55.

71. Falkowski, P.G.; Schofield, O.; Katz, M.E.; van de Schootbrugge, B.; Knoll, A. Why is the land green and the ocean red? In Coccolithophores: From Molecular Processes to Global Impact; Thierstein, H., Young, J.R., Eds.; Springer-Verlag: Berlin, Germany, 2004; pp. 429-453.

72. Tyrrell, T.; Taylor, A.H. A modelling study of Emiliania huxleyi in the NE Atlantic. J. Mar. Syst. 1996, 9, 83-112.

73. Andrusevich, V.E.; Engel, M.H.; Zumberge, J.E.; Brothers, L.A. Secular, episodic changes in stable carbon isotope composition of crude oils. Chem. Geol. 1998, 152, 59-72.

74. Cárdenas, A.; Harries, P.J. Effect of nutrient availability on marine origination rates throughout the Phanerozoic eon. Nat. Geosci. 2010, 3, 430-434.

75. Martin, R.E. Cyclic and secular variation in microfossil biomineralization: Clues to the biogeochemical evolution of Phanerozoic oceans. Glob. Planet. Chang. 1995, 11, 1-23.

76. Martin, R.E. Cyclic and secular trends in preservation through geologic time: Implications for the evolution of biogeochemical cycles. In Proceedings of International Conference Taphos 2002, Third Meeting on Taphonomy and Fossilization; Valencia, Spain, 14-16 February 2002; De Renzi, M., Alonso, M.V.P., Belinchón, M., Peñalver, E., Montoya, P., Márquez-Aliaga, A., Eds.; Gráficas Ronda, S.L.: Valencia, Spain, 2002; pp. 67-76.

77. Martin, R.E. The fossil record of biodiversity: Nutrients, productivity, habitat area and differential preservation. Lethaia 2003, 36, 179-193.

78. Jones, N. Cambrian's fiercest hunter defanged. Nature 2009, doi:10.1038/news.2009.811.

79. Signor, P.; Brett, C.B. The mid-Paleozoic precursor to the Mesozoic marine revolution. Paleobiology 1984, 10, 229-245.

80. Ausich, W.I.; Bottjer, D.J. History of tiering among suspension feeders in the benthic marineecosystem. J. Geol. Educ. 1991, 39, 313-318.

81. Solan, M.; Batty, P.; Bulling, M.T.; Godbold, J.A. How biodiversity affects ecosystem processes: Implications for ecological revolutions and benthic ecosystem function. Aquat. Biol. 2008, 2, 289-301.

82. Teal, L.R.; Parker, E.R.; Solan, M. Sediment mixed layer as a proxy for benthic ecosystem process and function. Mar. Ecol. Progr. Ser. 2010, 414, 27-40.

83. Lehnert, O.; Vecoli, M.; Servasis, T.; Nützel, A. Did plankton evolution trigger the Ordovician diversifications? Acta Palaeontol. Sinica 2007, 46, 262-268. 
84. Erwin, D.H.; Laflamme, M.; Tweedt, S.M.; Sperling, E.A.; Pisani, D.; Peterson, K.J. The Cambrian conundrum: Early divergence and later ecological success in the early history of animals. Science 2011, 334, 1091-1097.

85. Sepkoski, J.J.; Miller, A.I. Evolutionary faunas and the distribution of Paleozoic marine communities in space and time. In Phanerozoic Diversity Patterns: Profiles in Macroevolution; Valentine, J.W., Ed.; Princeton University Press: Princeton, NJ, USA, 1985; pp. 153-190.

86. Butterfield, N.J.; Knoll, A.H.; Swett, K. A bangiophyte red alga from the Proterozoic rocks of Arctic Canada. Science 1990, 250, 104-107.

87. Filippelli, G.M. Phosphorus and the gust of fresh air. Nature 2010, 467, 1052-1053.

88. Planavsky, N.J.; Rouxel, O.J.; Bekker, A.; Lalonde, S.V.; Konhauser, K.O.; Reinhard, C.T.; Lyons, T.W. The evolution of the marine phosphate reservoir. Nature 2010, 467, 1088-1090.

89. Finkel, Z.V.; Beardall, J.; Flynn, K.J.; Quigg, A.; Rees, T.A.V.; Raven, J.A. Phytoplankton in a changing world: Cell size and elemental stoichiometry. J. Plankton Res. 2010, 32, 119-137.

90. Thingstad, T.F.; Krom, M.D.; Mantoura, R.F.C.; Flaten, G.A.F.; Groom, S. Nature of phosphorus limitation in the ultraoligotrophic eastern Mediterranean. Science 2005, 309, 1068-1071.

91. Elser, J.J.; Watts, J.; Schampel, J.H.; Farmer, J. Early food-webs on a trophic knife-edge? Experimental data from a modern microbialite-based ecosystem. Ecol. Lett. 2006, 9, 295-303.

92. Zhuravlev, A.Y. Biotic diversity and structure during the Neoproterozoic-Ordovician transition. In The Ecology of the Cambrian Radiation; Zhuravlev, A.Y., Riding, R., Eds.; Columbia University Press: New York, NY, USA, 2001; pp. 173-199.

93. Cook, P.J.; McElhinny, M.W. A reevaluation of the spatial and temporal distribution of sedimentary phosphate deposits in the light of plate tectonics. Econ. Geol. 1979, 74, 315-330.

94. Huntley, J.W.; Xiao, S.; Kowalewski, M. 1.3 Billion years of acritarch history: An empirical morphospace approach. Precambrian Res. 2006, 144, 52-68.

95. Hayes, J.M.; Strauss, H.; Kaufman, A.J. The abundance of ${ }^{13} \mathrm{C}$ in marine organic matter and isotopic fractionation in the global biogeochemical cycle of carbon during the past 800 Ma. Chem. Geol. 1999, 161, 103-125.

96. Finkel, Z.V.; Katz, M.; Wright, J.; Schofield, O.; Falkowski, P.G. Climatically driven macroevolutionary patterns in the size of marine diatoms over the Cenozoic. Proc. Natl. Acad. Sci. USA 2005, 102, 8927-8932.

97. Finkel, Z.V.; Sebbo, J.; Feist-Burkhardt, S.; Irwin, A.J.; Katz, M.E.; Schofield, O.; Young, J.R.; Falkowski, P.G. A universal driver of macroevolutionary change in the size of marine phytoplankton over the Cenozoic. Proc. Natl. Acad. Sci. USA 2007, 104, 20416-20420.

98. Bottjer, D.J.; Hagadorn, J.W.; Dornbos, S.Q. The Cambrian substrate revolution. GSA Today 2000, 10, 1-7.

(C) 2012 by the authors; licensee MDPI, Basel, Switzerland. This article is an open access article distributed under the terms and conditions of the Creative Commons Attribution license (http://creativecommons.org/licenses/by/3.0/). 